\title{
Remembering, reflection and action: The evolution of the Aotearoa New Zealand Social Work journal
}

\author{
Margaret McKenzie and Mary Nash
}

Margaret McKenzie, is a Senior Lecturer in Social Work and Community Development, Otago University, where she is currently the Head of School. She has been a co-editor of Social Work Review. Mary Nash is a Senior Lecturer in social work, School of Health and Social Services, Massey University. She is a Life Member of ANZASW, and erstwhile editor of Social Work Review, and is currently co-editor of Aotearoa New Zealand Social Work Review

\section{Abstract}

This lead article in our vintage issue of Aotearoa New Zealand Social Work journal follows our professional journal from its launch in 1965, through several name changes, physical manifestations and numerous editorships, to the present day. Continuity and change are the themes we focus on, together with tenacity and adaptability. We briefly introduce the concept of content analysis as a tool for exploring the story of our journals and thus the Association's history, and end with reflective questions for the future.

\section{Introduction}

In 2004 during the 40th anniversary conference of the Aotearoa New Zealand Association of Social Workers, we presented a workshop that focused upon the archaeology of Social Work Review, as the journal was then called. The workshop was also a celebration of nearly 40 years of the publication of the Association's Journal of Social Work. Now that we have renamed the journal, it seems a fitting time to present this vintage issue to commemorate its history.

The five aims of the workshop that have guided this article were:

One: To remember, reflect and celebrate what has gone before by examining the archival content of our professional association's journal.

Two: To produce a topic timeline herstory/ history of Aotearoa New Zealand social work as found in Social Work Review.

Three: To trial a template for content analysis.

Four: To pass on skills in the technique of content analysis.

Five: To enable participants to help design some decade-by-decade herstory.

While this article is informed by that workshop, our priority is to put on record the story of the journal, and encourage current members to be aware of and have some tools to draw on the research and knowledge that has helped to shape our Association and develop our professional practice. We also hope that setting out a brief overview of the journal will encourage our readers to add to that store of research, knowledge and wisdom for future generations of social workers. 


\section{The publication story of the professional journal of ANZASW}

The first issue of the journal was published in August 1965: Vol 1, No 1, with the title: New Zealand Social Worker: News and Opinions. Aotearoa New Zealand Social Work, as it is now called, traces its origins to that first edition in August 1965, which was produced just 18 months after the birth of the NZASW itself. It was authorised by the National Council who announced its intention that it be a quarterly publication, aimed at disseminating information and communicating to the widely scattered membership.

From that point there has been a regular identifiable publication by the Association formally recognised as the journal of the Aotearoa New Zealand Association of Social Workers, apart from a gap between March 1976 and March 1977. While it has gone through various name changes and styles of presentation, most revealed by the diversity of titles and covers, and there have at times been some changes including hiccups and/or inconsistencies in the naming and numbering, it has remained a keystone of the Association.

At times these shifts can be seen to parallel events in the Association's history and approach. For example the first editions of Te Komako in 1995 and then Tu Mau in 2001 indicate significant points in the approach the Association has taken to bicultural and partnership issues within the Association, or the rise and fall of its fortunes, with issues ranging from glossy covered, back to 'gestetner produced' and then glossy again.

\section{Journal title and timeline}

The journal has been published under the following titles:

New Zealand Social Worker: News and Opinions

Vol 1, No 1, 1965 - Vol 5, No 2, 1969

The New Zealand Social Worker

Vol 5, No 3, 1969 - Vol 11, No 2, 1975

The New Zealand Social Worker Journal

December 1975 (Technically Vol 11, No 3)

March 1976 to March 1977 no journal produced.

New Zealand Social Work

Vol 1, No 1, 1977 - Vol 5, No 5, 1980

New Zealand Social Work - Journal

Vol 6, No 1, 1981 - Vol 8, No 3, 1983

New Zealand Social Work Journal

Vol 8, No 4, 1983 - Vol 12, Nos 3 \& 4, 1988

Social Work Review

Vol 1, No 1, 1988 - Vol XV, No 3, 2004

Vol XVI, No 4, 2004: New look cover

Aotearoa New Zealand Social Work

Vol XIX, No 2, 2007 
A particularly significant aspect of the history of the journal has been the development of Te Komako, with its first edition in 1995 and the annual publication since then, and of Tu Mau first published in 2001 and again in 2006.

Both these publications appear as journals within the journal, which is, so far as we know, a unique approach for a national association of social workers to provide space for the voice of groups within its association. While some journals do from time to time have special issues devoted to a topic, this approach by the Association journal recognises the status and mana that belongs to its Tangata Whenua and the Pasifika members. For example, both Te Komako and Tu Mau have their own editorial boards and editorial criteria for articles.

\section{Te Komako ${ }^{1}$ Timeline}

1. Te Komako 1

2. Te Komako 2

3. Te Komako 3

4. Te Komako 4

4. Te Komako 5

5. Te Komako 6

6. Te Komako 7

7. Te Komako 8

8. Te Komako IX

\section{Tu Mau Timeline}
1. Tu Mau
2. Tu Mau II

\author{
SWR Vol VII, No 1, 1995 \\ SWR Vol VIII, No 4, 1996 \\ SWR Vol XI, No 1, 1997 \\ SWR Vol XII, No 4, 2000 \\ SWR Vol XIV, No 2, 2002 \\ SWR Vol XV, No 3, 2003 \\ SWR Vol XVI, No 2, 2004 \\ SWR Vol XVII, No 2, 2005 \\ SWR Vol XVIII, No 2, 2006
}

Harry Walker wrote the editorial for the first issue of Te Komako. He emphasised the historic nature of that first issue, for it demonstrated 'the growing awareness of the numerous Maaori views of healing processes, analysis, reflections and challenges which come within the gamut of what we call social work' (Walker, 1995: 1). Mason Durie contributed the lead article, 'Maaori and the State: Professional implications for a bicultural practice', followed by an article by John Bradley: 'Totara tree without roots'. Mary Nash recalls John Bradley broaching the Editorial Board with the possibility of a Maori series of issues for SWR and the enthusiasm which the project generated.

Tu Mau first came out in Spring 2001, with a vivid blue front cover and an evocative editorial by Christina Newport and Tracie Mafile'o which welcomed readers to the richness of the Pacific. I encourage readers to find a copy and read it, for when they say 'What you have in your hands is more than print on paper' they mean it (Newport and Mafile'o, 2001: 1).

\section{Why is this story important?}

Published literature, especially in a national journal is important to a professional association. Several writers identify this. Spender (1981) wrote that published literature has the power to establish the issues in a discipline and to legitimise the parameters of debate. Journals

1 Our records, which are confirmed as correct by staff at the Hocken Library, show that there is a numbering problem for two issues of Te Komako. Jan 1997 Vol XII should have been December Vol XI, and the 2000 issue does not have its date printed on the outside cover. 
have generally been regarded as a prime means of documenting and disseminating the current knowledge base and scholarly output of a profession (Ryan and Martyn, 1996: 19), and enabling the development of professional knowledge (Nichols-Casebolt, et al., 1994), of providing a professional whakapapa, genealogy.

Analysis of journal content and articles allows the reader to assess the contribution of the journal to professional knowledge and development, particularly when the material covered in such journals communicates what is considered important in the field. What is included or omitted can directly or indirectly signal the level of importance placed on particular issues over time (Grise-Owens, 2002: 147).

Thus our journal is a prime site for an archaeological dig into the knowledge base of New Zealand social work, providing a critical lens with which to track the historical development of the profession and its knowledge base.

In 2005, Merv Hancock and Mary Nash wrote a joint article inspired by the workshop on an archaeology of Social Work Review. Reflecting on the first issue of our professional journal, Hancock (2005: 23) recalled that:

The journal was to be published quarterly: August, November, February, May. There were instructions in that first introductory News and Opinions about when to supply script. It turned out to be extremely valuable and from its first publication in August 1965 there has been a continuous line of publications by the Association. The title has changed from the New Zealand Social Worker to other titles and various approaches have been adopted by different editorial groups but there has been a continuous line of communication within members since the beginning. The first edition proved a major success and has gone on to remain so (Hancock and Nash, 2005: 23).

Themes represented in this first issue have been of perennial interest to readers.

First we noted education and training for social workers, including national, local and in-service training opportunities, many provided by the Association for its members.

A second and significant theme was the membership question as illustrated below:

This has been a perennial issue for the Association, so it is not surprising it emerges in the first issue of the journal. 'The membership question' (New Zealand Social Worker, 1, 1: 13) deals in part with the controversies surrounding associate membership but also refers to the Constitution which empowered to the National Council to set up the register of approved agencies and categories of employment. The regulations were designed to ensure that full members control the Association. The membership was kept as wide open as possible and whilst there was a clause which entitled those with approved social work qualifications to full membership, other clauses ensured that this was not an exclusive membership criterion. This device was the fundamental difference between the developments in Australia where the social workers' association was based entirely around approved academic qualifications for full membership and the New Zealand solution which was more open (Hancock and Nash, 2005: 27).

At the bottom of the cover page of the first and subsequent editions of the journal one finds the leading original Association logo and beside it is laid out the membership basis for the Association. This information on the front cover was very important to public understanding of who could and could not belong to the Association. 
Conferences and their coverage was another theme we picked out from that first issue and we commented on how important networking and the exchange of ideas has been in the development of social work in New Zealand. Attendance at conferences, reporting back to members, and running our own conferences were all seen to be necessary ingredients of a professional association from the start.

Generic social work and diversity of practice were depicted in the journal because as social work developed a sense of identity, so it recognised the variety of work encompassed in the name of 'social work' not to mention evolving fields of practice.

Social work still occurs, as it did in the 1960s, in a variety of settings, statutory and voluntary, religious and secular.

First issue of The New Zealand Social Worker: News and Opinions, 1965.

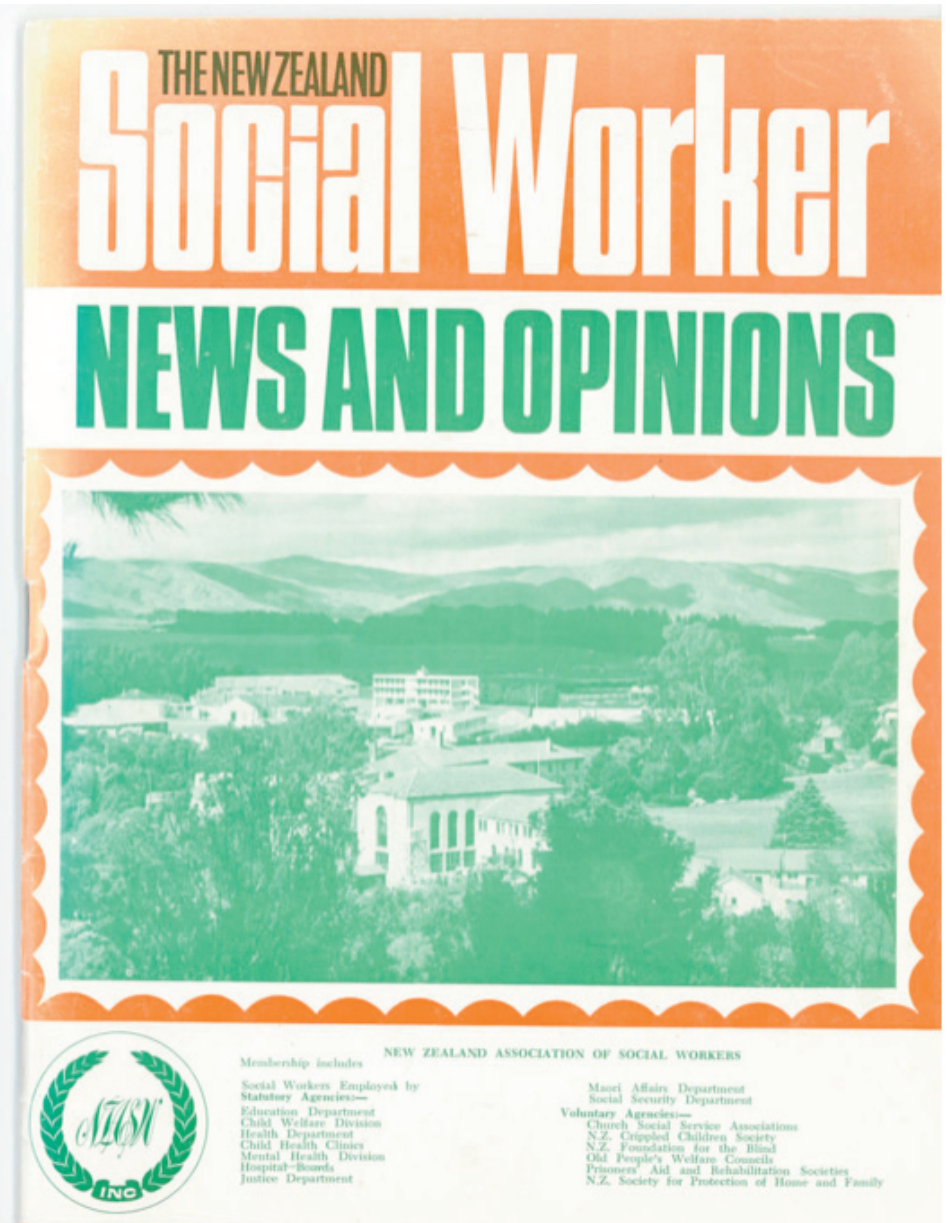


The final theme we picked out was 'News from the Branches' and Merv Hancock noted that:

\begin{abstract}
'News from the Branches' has been a regular feature in the Association's publications and one well worth the attention of the researcher who wants to discover what activities brought social workers together in the regions. Many of the people named in this section are foundation members, and one could argue that a separate article based on the people and activities covered here would yield rich information relating to those who played significant parts in these early years of the Association (Hancock and Nash, 2005: 30).
\end{abstract}

We now look to Social Work Noticeboard for much of this information. Perhaps future readers and historians will wish the journal, being more accessible to students and researchers than Noticeboard, carried more of this category of information. Hancock and Nash's (2005) article ended reflectively, suggesting that early issues of the journal would reward our members who study them. It similarly noted the continuities and changes that make up our professional development, namely the debates about membership, issues around identity, qualifications, education and training, how to find time and money to attend conferences, fields of practice and client concerns are all recorded and 40 years on, they still matter to us.

In examining the jkournal, some key questions we can ask are:

- What has been the social work response to changing times?

- What have social work authors recommended about social work practice in a professional journal that seeks to promote ideas and knowledge to its membership?

- What have our members been doing to promote evidence-based practice through their research and writing?

\title{
Using content analysis to grow the story of social work in Aotearoa New Zealand
}

An introduction to the ideas and principles of content analysis was used at the 40th anniversary workshop as a way into this task. Content analysis is a research method, where systematic and objective inferences about content are made to categorise, manage and order the occurrence of diverse content within a text or texts. Selection criteria are consistently applied to determine inclusion to the categories being investigated. It is an approach that is useful for determining trends or patterns, tracing developments over time and inferring cultural change, values and interests (Tripodi and Epstein, 1980, in McMahon, 2002: 173).

Such a content review can take place in two stages, first by a content analysis that measures the occurrence of selected items within the text/texts and secondly by a critical discourse analysis, a method for in-depth analysis of content, theme and influence from the content analysis findings.

\section{Content analysis}

An initial content analysis of the Association's journal would involve reviewing each issue's contents pages and systematically identifying the overall characteristics of the content. Con- 
tent pages can be reviewed by a physical search or if available, an online search. Content analysis can tell a researcher how many texts/items of a particular type/category appear over time and at what rate. This approach is useful for determining trends or patterns, tracing developments over time, for example on a decade-by-decade basis and inferring cultural and social influences, when the topic became of interest (when the first article covering a new topic first appears), and whether there was / is a high point in its interest, a special edition/ single topic issue. One can ask what is the longevity or otherwise of a topic? How often was it written about? When was its peak time? Who is writing, about what and when? All these questions are a means of establishing overall parameters for a history of social work in Aotearoa New Zealand. Table 1, provides a simple format for recording initial content analysis findings, by recording the occurrences by author and title of one subject though a decade. $^{2}$

Table 1. Content analysis - articles by decade by subject.

\begin{tabular}{|l|l|l|l|l|}
\hline $\begin{array}{l}\text { Decade / } \\
\text { Subject/ }\end{array}$ & \multicolumn{3}{|c|}{ Subjects } \\
\hline Decades & Child Protection & Youth Justice & Mental Health & Ageing \\
\hline 1960 s & Author/Title/Date & Author, Title, Date & & \\
\hline 1970 s & Author, Title, Date & & & \\
\hline 1980 s & & & & \\
\hline 1990 s & & & & \\
\hline 2000 s & & & & \\
\hline 2010 & & & & \\
\hline
\end{tabular}

\section{Critical discourse analysis}

In the second part of the process, critical discourse analysis (see Table 2), a subject/theme analysis is undertaken with the unit of analysis being the content within an identified article. Detailed sub-categories and classification of the content more specifically identifies the content, for example research, policy, education, practice. This can include a range of possible foci: why is it there, why might it occur at this point of time, what influences does it reflect? According to Rojek, et al. (1988: 8 in McMahon, 2002: 174) '... discourse theory examines the language, knowledge, myths and assumptions that underpin a particular manifest position'. (McMahon, 2002: 174) adds that 'Critical discourse analysis focuses on how the texts under scrutiny function in forming and shaping practice'.

2 We have included examples of content analysis and discourse analysis relating to the coverage of supervision in the journal, at the end of this article. These have been contributed by Kieran O'Donoghue and show how these two tables can be used. 
Table 2. Critical discourse analysis - articles by subject and theme.

\begin{tabular}{|l|l|l|l|l|}
\hline Theme & Research & Practice & Policy & Education \\
\hline $\begin{array}{l}\text { Subject } \\
\text { Ageing }\end{array}$ & $\begin{array}{l}\text { Author, Title, } \\
\text { Date }\end{array}$ & $\begin{array}{l}\text { Author, Title, } \\
\text { Date }\end{array}$ & & \\
\hline Mental Health & $\begin{array}{l}\text { Author, Title, } \\
\text { Date }\end{array}$ & & & \\
\hline Child Protection & & & & \\
\hline Youth Justice & & & & \\
\hline
\end{tabular}

An excellent example, combining both a decade content analysis and critical discourse content analysis, the only one that has appeared in our journal, 'Reviewing the review: A review of the ANZASW Social Work Review journal from 1988-2000', Whibley-Smith, Selby and Baskerville (2002) illustrates the possibilities for this type of work.

This process of analysis provides evidence from which to interpret and explain the cultural assumptions, social relationships and social identities incorporated in the texts (articles), (Fairclough, 1992: 38, in McMahon, 2002: 174) and thus enables research into the relationship between social work texts and social work practice. It can make explicit what Fairclough (1992: 166 in McMahon, 2002: 174) calls 'the ideological and hegemonic effects, portrayed in patterns (themes) of knowledge and beliefs, social relations and social identities'. In other words, it provides us with a traceable means of understanding the interconnections OR intersections between the concerns of our profession and the development and foci of social work practice.

\section{Conclusion}

Using such tools, we can develop a New Zealand social work history derived from the pages of our professional association's journal. We can form a meaningful picture of what and how we have written and published during the last 40 years. The example of articles covering supervision, in the appendix, shows how clearly this information is portrayed using this tool. Research based on content and discourse analysis helps to answer questions such as what has influenced us, and what influence have we had? Do our articles reflect or challenge the social and political circumstances in which they were written and their subjects lived? Have we shaped or been shaped by our history? What can we learn from them about changes in social work education, the status of social work and how it has been practised?

With such an understanding, we can then ask how will we be writing in the next 40 years? This would be a fruitful research area for students and historians and now is a good time to embark on such research, while so many of the early contributors are still available to provide oral histories and an explanation for what is on record. 


\section{References}

Bradley, J. (1995). Totara tree without roots. Te Komako, Social Work Review, VII(1), 6-8.

Durie, M. (1995). Maaori and the State: Professional implications for a bicultural practice. Te Komako, Social Work Review, VII(1), 2-5.

Grise- Owens, E. (2002). Sexism and the social work curriculum: A content analysis of the Journal of Social Work Educaton. Afilia, 17, 147-168.

Hancock, M. and Nash, M. (2005). The first two years of the New Zealand Association of Social Workers 1964-66: Reflections on rereading the first issue of the New Zealand Social Worker. Social Work Review, XVII(1), 23-30.

McMahon, A. (2002). Writing diversity: Ethnicity and race in Australian Social Work 1947-1997. Australian Social Work, 55(3), 172-183.

New Zealand Association of Social Workers (Inc.). (1965). New Zealand Social Worker, 1(1).

Newport, C. and Mafile'o, T. (2001). Tu Mau, Social Work Review, XIII(3), 1-2.

Nichols-Casebolt, A., Krysik, J., \& Hamilton, B. (1994). Coverage of womens' issues in social work journals. Journal of Social Work Education, 30, 348-362.

Ryan, M. and Martyn, R. (1996). Writing about social work education: A content analysis of Australian journal articles 1983-93. Australian Social Work, 49(4), 19-23.

Spender, D. (1981). The gatekeepers. In H. Roberts, Doing feminist research, pp. 186-202. London: Routeldge and Kegan Paul.Walker, H. (1995). Editorial. Te Komako, Social Work Review, VII(1), 1.

Whibley-Smith, A., Selby, R., \& Baskerville, M. (2002). Reviewing the review: A review of the ANZASW Social Work Review Journal from 1988-2000. Social Work Review, XIV(14), 6-9.

\section{Appendix}

Table 1. Content analysis: articles by decade by subject. Example: supervision within the Association's journal.

\begin{tabular}{|c|c|}
\hline $\begin{array}{l}\text { Decade / } \\
\text { Subject/ }\end{array}$ & $\begin{array}{l}\text { Subjects } \\
\rightarrow\end{array}$ \\
\hline Decades $\downarrow$ & Supervision \\
\hline $1960 s$ & $\begin{array}{l}\text { New Zealand Association of Social Workers. (1966). Report of supervision in } \\
\text { social work course Oct-Nov 1965. New Zealand Social Worker, 2(1), } 21 . \\
\text { Austin, T., \& Buxton, W. (1969). Training for the future of social workers in } \\
\text { New Zealand. New Zealand Social Worker, } 5 \text {. } \\
\text { Rees, H. (1969). Supervision of medical social workers in training. New Zealand } \\
\text { Social Work 5, 43-47. }\end{array}$ \\
\hline 1970s & $\begin{array}{l}\text { Te Uira, I. (1973). The problems of continuing in-service training and supervi- } \\
\text { sion in the field. New Zealand Social Worker, } 9(4), 35-41 \text {. } \\
\text { Bracey, O. (1978). A conspiracy of silence or supervision in social work in NZ. } \\
\text { New Zealand Social Work, 2(2), 9-12. } \\
\text { Hessey, E. (1978). Group supervision for social workers - an experiment for } \\
\text { growth or survival. New Zealand Social Work, 2(4), 12-14. }\end{array}$ \\
\hline 1980s & $\begin{array}{l}\text { Read, L. (1983). Supervision in social work - some thoughts, New Zealand } \\
\text { Social Work, 9(2), 7-8. } \\
\text { Blake-Palmer, L., \& Connolly, M. (1989). Supervision - but not as we know } \\
\text { it! Social Work Review, 2(2\&3), 21-22. } \\
\text { Taverner, P. (1989). Supervision. Social Work Review, 1(3\&4), 20-21. }\end{array}$ \\
\hline 1990s & $\begin{array}{l}\text { Beddoe, L., \& Davys, A. (1994). The status of supervision - reflections from } \\
\text { a training perspective. Social Work Review, 6(5/6), 16-21. } \\
\text { Cockburn, G. (1994). Supervision in social work: A brief statement of the es- } \\
\text { sentials. Social Work Review, } 6(5 / 6), 37 \text {. }\end{array}$ \\
\hline
\end{tabular}




\begin{tabular}{|c|c|}
\hline & $\begin{array}{l}\text { Young, G. (1994). Critical components in the supervision of child protection } \\
\text { social workers in a statutory agency. Social Work Review, 6(5/6), 23-29. } \\
\text { Beddoe, L. (1997). Best practice in social work supervision - education and } \\
\text { accreditation issues. Social Work Review, 9(4), 37-43. } \\
\text { O'Donoghue, K., Trlin, A.D. \& Baskerville, M. (1999). Professional supervision } \\
\text { in the new managerial climate of the Department of Corrections. Social Work } \\
\text { Review, 11(1), 8-15. } \\
\text { Bradley, J., Jacob, E., \& Bradley R. (1999). Reflections on culturally safe su- } \\
\text { pervision, or why Bill Gates makes more money than we do. Te Komako III, } \\
\text { Social Work Review, 11(4), 3-6. } \\
\text { Webber-Dreadon, E. (1999). He taonga mo o matou tipuna (A gift handed } \\
\text { down by our ancestors): An indigenous approach to social work supervision. } \\
\text { Te Komako III Social Work Review, 11(4), 7-11. }\end{array}$ \\
\hline $2000 \mathrm{~s}$ & $\begin{array}{l}\text { Morrell, M. (2001). External supervision - confidential or accountable? An } \\
\text { exploration of the relationship between agency, supervisor and supervisee. } \\
\text { Social Work Review, 13(1), 36-41. } \\
\text { O'Donoghue, K. (2001). The future of social work supervision within New } \\
\text { Zealand. Social Work Review, 13(1), 29-35. } \\
\text { O'Donoghue, K. (2002). Global-vision, local-vision, personal-vision and social } \\
\text { work supervision. Social Work Review, 14(4), 20-25. } \\
\text { Morrell, M. (2003). Forethought and afterthought - two of the keys to pro- } \\
\text { fessional development and good practice in supervision. Social Work Review, } \\
\text { 15(1/2), 29-32. } \\
\text { Bell, H., \& Thorpe, A. (2004). External supervision: What is it for a social } \\
\text { worker in schools? Te Komako VII, Social Work Review, 16(2), 12-14. } \\
\text { Walsh-Tapiata, W., and Webster, J. (2004). Do you have a supervision plan? } \\
\text { Te Komako VII, Social Work Review, 16(2), 15-19. } \\
\text { O'Donoghue, K. (2004). Social workers and cross-disciplinary supervision. } \\
\text { Social Work Review, 16(3), 2-7. } \\
\text { Davys, A. (2005). At the heart of the matter: Culture as a function of supervi- } \\
\text { sion. Social Work Review, 17(1), 3-12. } \\
\text { Gillanders, M. (2005). The hidden power of the written word: Record-keeping } \\
\text { in supervision. Social Work Review, 17(3), 2-9. } \\
\text { Morrell, M. (2005). Supervision - an effective partnership: The experience of } \\
\text { running workshops for supervisees in 2004-2005. Social Work Review, 17(4), } \\
\text { 39-45. } \\
\text { O'Donoghue, K., Munford, R., \& Trlin, A. (2005). Mapping the territory: } \\
\text { Supervision within the Association. Social Work Review, 17(4), 46-64. } \\
\text { Cooper, L. (2006). Clinical supervision: Private arrangement or managed } \\
\text { process? Social Work Review, 18(3), 21-30. } \\
\text { Garland, M., \& Ellis, G. (2006). Synergistic supervision. Social Work Review, } \\
\text { 18(3), 31-42. } \\
\text { O'Donoghue, K., Munford, R., \& Trlin, A. (2006). What's best about social work } \\
\text { supervision according to Association members. Social Work Review 18(3), 79- } \\
\text { 91. } \\
\text { Hanna, S. (2007). Not so strange! An application of attachment theory and } \\
\text { feminist psychology to social work supervision. Aotearoa New Zealand Social } \\
\text { Work Review, 19(3), 12-22. } \\
\text { Rains, E. (2007). Interdisciplinary supervisor development in a community } \\
\text { health service. Aotearoa New Zealand Social Work Review, 19(3), 58-65. }\end{array}$ \\
\hline
\end{tabular}


Table 2. Critical discourse analysis: supervision articles by theme.

\begin{tabular}{|c|c|}
\hline Theme & Supervision \\
\hline Research & $\begin{array}{l}\text { Bracey, O. (1978). A conspiracy of silence or supervision in social work in } \\
\text { NZ. New Zealand Social Work, 2(2), 9-12. } \\
\text { Young, G. (1994). Critical components in the supervision of child protection } \\
\text { social workers in a statutory agency. Social Work Review, (5/6), 23-29. } \\
\text { O'Donoghue, K., Trlin, A.D., \& Baskerville, M. (1999). Professional supervi- } \\
\text { sion in the new managerial climate of the Department of Corrections. Social } \\
\text { Work Review, 11(1), 8-15. } \\
\text { O'Donoghue, K., Munford, R., \& Trlin, A. (2005). Mapping the territory: } \\
\text { Supervision within the Association. Social Work Review, 17(4), 46-64. } \\
\text { Cooper, L. (2006). Clinical supervision: Private arrangement or managed } \\
\text { process? Social Work Review, 18(3), 21-30. } \\
\text { Rains, E. (2007). Interdisciplinary supervisor development in a community } \\
\text { health service. Aotearoa New Zealand Social Work Review, 19(3), 58-65. } \\
\text { O'Donoghue, K., Munford, R., \& Trlin, A. (2006). What's best about social } \\
\text { work supervision according to Association members. Social Work Review, } \\
\text { 18(3), 79-91. }\end{array}$ \\
\hline Practice & $\begin{array}{l}\text { Hessey, E. (1978). Group supervision for social workers - an experiment for } \\
\text { growth or survival. New Zealand Social Work, 2(4), 12-14. } \\
\text { Read, L. (1983). Supervision in social work - some thoughts. New Zealand } \\
\text { Social Work, 9(2), 7-8. } \\
\text { Blake-Palmer, L., \& Connolly, M, (1989). Supervision - but not as we know } \\
\text { it! Social Work Review, 2(2\&3), 21-22. } \\
\text { Taverner, P. (1989). Supervision. Social Work Review, 1(3\&4), 20-21. } \\
\text { Cockburn, G. (1994). Supervision in social work: A brief statement of the } \\
\text { essentials. Social Work Review, 6(5/6), 37. } \\
\text { O'Donoghue, K. (2002). Global-vision, local-vision, personal-vision and social } \\
\text { work supervision. Social Work Review, 14(4), 20-25. } \\
\text { Morrell, M. (2003). Forethought and afterthought - two of the keys to pro- } \\
\text { fessional development and good practice in supervision. Social Work Review, } \\
\text { 15(1/2), 29-32. } \\
\text { Bell, H., \& Thorpe, A. (2004). External supervision: What is it for a social } \\
\text { worker in schools? Te Komako VII, Social Work Review, 16(2), 12-14. } \\
\text { O’Donoghue, K. (2004). Social workers and cross-disciplinary supervision. } \\
\text { Social Work Review, 16(3), 2-7. } \\
\text { Davys, A. (2005). At the heart of the matter: Culture as a function of supervi- } \\
\text { sion. Social Work Review 17(1), 3-12. } \\
\text { Garland, M., \& Ellis, G. (2006). Synergistic supervision. Social Work Review } \\
\text { 18(3), 31-42. } \\
\text { Hanna, S. (2007). Not so strange! An application of attachment theory and } \\
\text { feminist psychology to social work supervision. Aotearoa New Zealand Social } \\
\text { Work Review 19(3), 12-22. }\end{array}$ \\
\hline Education & $\begin{array}{l}\text { New Zealand Association of Social Workers. (1966). Report of supervision } \\
\text { in social work course Oct-Nov 1965. New Zealand Social Worker 2(1), } 21 . \\
\text { Austin, T., \& Buxton, W. (1969). Training for the future of social workers in } \\
\text { New Zealand. New Zealand Social Worker, 5(1), } 5 \text {. } \\
\text { Rees, H. (1969). Supervision of medical social workers in training. New Zealand } \\
\text { Social Work, 5, 43-47. }\end{array}$ \\
\hline
\end{tabular}




\begin{tabular}{|l|l|}
\hline & $\begin{array}{l}\text { Te Uira, I. (1973). The problems of continuing in-service training and supervi- } \\
\text { sion in the field. New Zealand Social Worker, 9(4), 35-41. } \\
\text { Beddoe, L., \& Davys, A. (1994). The status of supervision - Reflections from } \\
\text { a training perspective. Social Work Review, 6(5/6), 16-21. } \\
\text { Morrell, M. (2005). Supervision - an effective partnership: The experience of } \\
\text { running workshops for supervisees in 2004-2005. Social Work Review, 17(4), } \\
\text { 39-45. }\end{array}$ \\
\hline Policy & $\begin{array}{l}\text { Beddoe, L. (1997). Best practice in social work supervision - Education and } \\
\text { accreditation issues. Social Work Review, 9(4), 37-43. } \\
\text { Morrell, M. (2001). External supervision - Confidential or accountable? An } \\
\text { exploration of the relationship between agency, supervisor and supervisee. } \\
\text { Social Work Review, 13(1), 36-41. } \\
\text { O'Donoghue, K. (2001). The future of social work supervision within New } \\
\text { Zealand. Social Work Review, 13(1), 29-35. } \\
\text { Gillanders, M. (2005). The hidden power of the written word: Record-keeping } \\
\text { in supervision. Social Work Review, 17(3), 2-9. }\end{array}$ \\
\hline Maori supervision & $\begin{array}{l}\text { Bradley, J., Jacob, E., \& Bradley R. (1999). Reflections on culturally safe su- } \\
\text { pervision, or why Bill Gates makes more money than we do. Te Komako III, } \\
\text { Social Work Review, 11(4), 3-6. } \\
\text { Webber-Dreadon, E. (1999). He taonga mo o matou tipuna (A gift handed } \\
\text { down by our ancestors): An indigenous approach to social work supervision. } \\
\text { Te Komako III, Social Work Review, 11(4), 7-11. } \\
\text { Walsh-Tapiata, W., \& Webster, J. (2004). Do you have a supervision plan? Te } \\
\text { Komako VII, Social Work Review, 16(2), 15-19. }\end{array}$ \\
\hline
\end{tabular}

